\title{
Drilling the outback
}

\author{
Beneath the dust and hummock grass of the remote Pilbara region of Western Australia, \\ Pascal Philippot and Martin Van Kranendonk searched for signs of ancient life in some of the \\ oldest rocks recovered on Earth.
}

\begin{abstract}
What was the objective of the work? The Pilbara Drilling Project arose through an intense desire to try to determine whether the previously recognized, but highly controversial, accretionary layered stromatolite fossils and microfossils in deeply weathered surface outcrops of these ancient rocks could in fact be signs of the earliest preserved life on Earth.
\end{abstract}

\section{Why did you choose this particular} location for the fieldwork?

For the past 30 years, the putative stromatolite remains that were discovered in the 3.5 billion-year-old rocks of the North Pole locality of the Pilbara region have been tentatively accepted as evidence for early life on Earth. However, some structures that superficially resemble fossil stromatolites can also be formed by non-biological processes. We chose to drill the North Pole site as well as the 2.7 billion-year-old Tumbiana Formation, which represents one of the best late Archaean sites where large and diverse fossil stromatolites are preserved. The goal was to analyse geochemical signals from the fossil remains from these two different, but complementary, settings to try to discover proxies that indicate a clearly biological origin.

\section{What sorts of data or samples were} you after?

In the cores we were planning to take, we were hoping to find fresh unweathered sedimentary rocks containing stromatolites, microfossils, diagenetic crystals, organic matter and fluid inclusions. We also collected drilling fluids and specific core samples

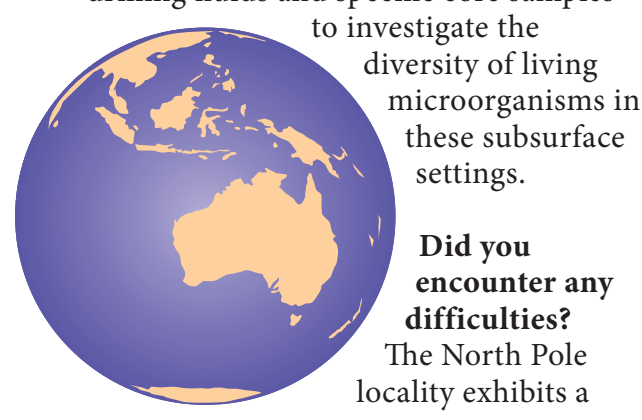

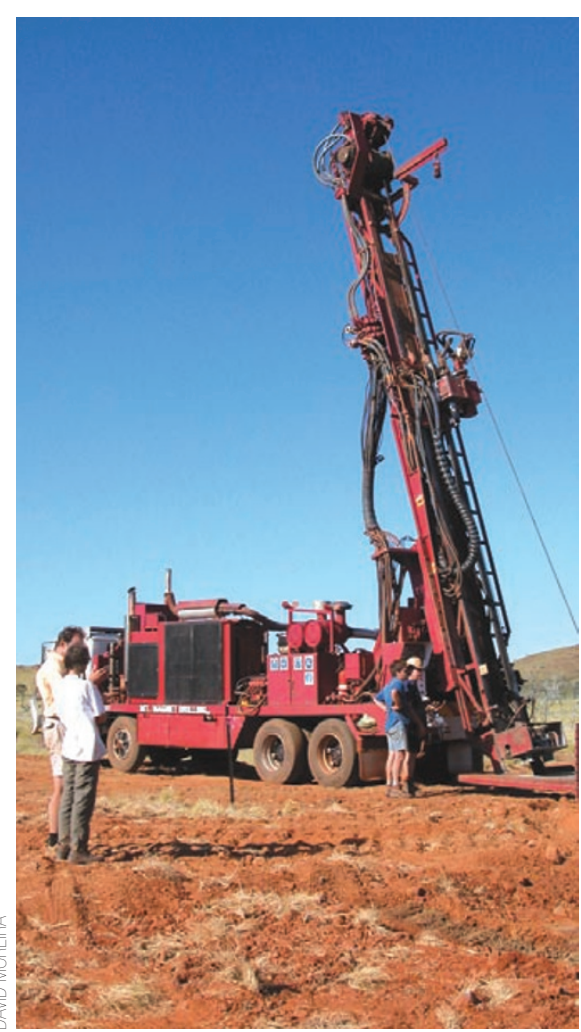

Orientation of the diamond drill rig at about $90^{\circ}$ to the sedimentary layering (Tumbiana locality). First row, Purificación López-García and Martin Van Kranendonk. Second row, Pascal Philippot and drilling contractor, Paul Van Loenhout.

complex geology, and we had to persuade our funding agencies who felt that, because of the complex geology and high probability of missing the target layers, the locality was too risky to warrant the high cost of drilling. Owing to various complications and delays, we had only one day to spare when we were able to bring in a bulldozer to clear the way and make a path for the drill rig. Drilling the Tumbiana Formation was much easier because the sequence is flat lying and relatively homogeneous. In both localities, we managed to obtain cores through the full sections of the sediments that could contain fossils.
Did you have encounters with dangerous animals? Any low points, close misses?

At the end of the drilling expedition, we were left with five of us in a single fourwheel drive that was loaded with a ton of drill core, and less than two days to drive the $2,000 \mathrm{~km}$ journey from the Pilbara to Perth. That gave us only a few more days to cut the $500 \mathrm{~m}$ of drill cores into halves and freight half of it back to Paris. During winter, the most dangerous driving hazards are kangaroos and cattle crossing the highway at night time. As we had to get to Perth in two days, it meant dodging myriads of unpredictable marsupials standing along the road, ready to jump into our path.

\section{What was the highlight of the expedition?}

After two unsuccessful attempts of diamond drilling the North Pole locality due to highly weathered basalts that broke the drill rig, we decided to change strategy and undertake percussion drilling. At $84 \mathrm{~m}$ depth, after powdering out a large volume of monotonous green basaltic rocks, the first flakes of red jasper came out of the drill stem at about 2 oclock in the morning. We knew then that we were going to achieve our goals.

Did the trip give you any ideas for future research projects?

The Barberton greenstone belt of the Kaapvaal Craton in South Africa represents the second region in the world found to contain weakly metamorphosed and well preserved rocks of 3.5 to 2.8 billion years in age. In 2007, we initiated a new drilling project with colleagues from South Africa and Norway to recover sedimentary rock sequences similar to the core sections studied in the Pilbara.

Pascal Philippot of the Institut de Physique du Globe de Paris and Martin Van Kranendonk of the Geological Survey of Western Australia wrote this Backstory to the work by Kevin Lepot and colleagues, published on page 118 of this issue. 